\title{
Online Payment Gateways and the Expediency of Their Use in Small to Medium-Sized Internet Shops in Ukraine
}

\author{
Yuliya Peretiatko \\ Department of Accounting, \\ Taxation and Audit \\ Chernihiv National University \\ of Technology \\ Chernihiv, Ukraine \\ yuliaperetiatko@gmail.com
}

\author{
Tetiana Klymenko \\ Department of Accounting, \\ Taxation and Audit \\ Chernihiv National University \\ of Technology \\ Chernihiv, Ukraine \\ klemenkotv79@gmail.com
}

\author{
Alexander Sidorenko \\ Department of Accounting, \\ Taxation and Audit \\ Chernihiv National University \\ of Technology \\ Chernihiv, Ukraine \\ sidorenko_aleks85@ukr.net
}

\begin{abstract}
A very important aspect of a functional Internet store is the process of accepting payment for goods or services from customers. Payment methods can be classified online and offline. Major international and local Ukrainian payment gateways and their fees and features were analyzed. As a result threshold of a minimum monthly store turnover was defined, where offline manual payment processing is no longer reasonable. Best payment gateways by the different criteria were defined. Online and offline payment processing expenses for a small and medium-sized internet stores in Ukraine were estimated using a mathematical model that included average order value, monthly store sales amount, worker salary amount and manual transaction processing time. As a result, offline payment processing is less expensive for the most of the small and medium stores, and online payment processing is effective for stores with a large number of small orders. Despite having almost equal transaction fees, Ukrainian payment gateways have fewer features and less trust by the international customers, but the usage of the most international services are not possible in Ukraine because of legal issues.
\end{abstract}

Keywords - payment processing, internet payment gateway, transaction fee, chargeback, dispute handling, offline payment processing

\section{INTRODUCTION}

To get paid for goods and services Internet store owners use internet payment service providers. It is a merchant service provided by an e-commerce application service provider that authorizes credit card processing. There are many different payment service providers, offering their services with different setup procedures, fees, additional features. Well known companies offering internet payment processing are PayPal, Amazon.

Significant contribution to the research of payment systems was made by S.V. Zasanska, N.P. Yurchuk, Y.V. Mashik. S.V. Zasanska in her work [1], explores the nature, functions and principles of electronic payment transactions. N.P. Yurchuk [2] explores the international experience of using electronic payments for their use by the domestic companies. Particularly noteworthy is the work of Y.V. Mashik [3], which investigates the personalities of the functioning of electronic payment systems such as "RBK Money (RUpay)", "Internet. Money", "E-gold", "PayPal", "Yandex.Money". Not to lessen the value of the results obtained by scientists, it should be noted that every year new and improved payment systems appear on the market. Moreover, the effectiveness of payment systems in the scientific community was not widely reported.

Many beginner e-store owners in Ukraine do not use online payment processing, giving preference to manual payment processing using direct card to card payments. Reasons are: they don't want to pay additional fees for online card processing; often they don't know how to integrate payment processing into their e-store software. But increasing store turnover leads to a huge amount of manual work, so it may become ineffective at some point.

The goal of the article is to analyze different payment service providers can compare them by their setup fees, monthly fees, transaction fees, and additional features offered. Also we will calculate threshold of the volume of sales that makes transition from the manual payment processing to the automated online payment processing fully justified.

\section{METHODS}

We compared 8 most popular international (Fig. 1) and 3 Ukrainian payment service providers by their fees, supported currencies and additional features. eWay and Sage pay are not included in the study, because the are not internationally available.

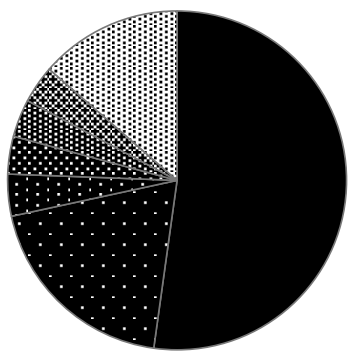

- PayPal 52,2\%

- Authorize.net $19,4 \%$

Dtripe $4,0 \%$

eWay $3,6 \%$

明 Braintree 3,6\%

SagePay $3,6 \%$

国 Others $13,6 \%$

Fig. 1. Payment service provider breakdown [4] 
Setup fee is a one time payment and all payment service providers offer free setup.

Transaction fee - amount paid to provider from each processed transaction. International payment service providers use formula with a fixed part plus a percentage of the transaction amount, while Ukrainian - just percentage amount.

Monthly fee - amount deducted from the store owner account monthly, without taking into account number of the transaction during that month. International payment service providers fixed and percent part in this fee, while Ukrainian providers use simple percent formula.

Chargeback fee - fixed amount fine, paid by the store owner if the payment is reverted by the customer's bank. Chargeback mechanism is created for consumer protection. In case of the fraudulent transaction, problems with delivery of goods or their quality, customer may initiate a chargeback procedure by contacting their bank and filling complaint regarding this transaction. Chargebacks are usually not allowed for transactions confirmed by the customer using additional security authentication (3-D Secure).

Number of currencies supported by the payment service provider - usually customers like to pay in their local currency to avoid exchange fees, and large number of supported currencies is good for stores selling goods internationally.

Most payment processors offer different kinds of fraud protection services for their clients. Their aim is to estimate fraud probability for each transaction, based on credit card details, delivery address, customer IP address, etc. For example if payment service provider detects that customer entered incorrect billing address ZIP or current customer country detected using GeoIP services are in the high-risk list - transaction may be declined. Also sellers can set their own white or black lists of the countries, to prevent fraudulent orders from the high-risk countries (East Europe, Africa, Asia).

Dispute handling is another service created for the convenience of the customers. In case of any dispute between seller and customer (order lost in transit, wrong item sent, or customer is dissatisfied with the goods quality), that can't be solved by the direct communication between two parties, payment service provider takes the role of the arbiter, evaluates arguments and evidences sent by both parties and provides decision. This feature helps to make internet store more credible and helps to build trust and confidence in internet commerce world.

Recurring payments, also called subscription payments are the payments, which paid by the customer at the regular basis (usually monthly or yearly). This feature is useful for companies selling services (for example website hosting or internet TV) but can be used also by e-stores to sell goods to their regular customers: deliver fresh bread or milk few times a week or flowers every year for some important date.

In the following Table I. we summarized that data for most used international and Ukrainian payment processors.

TABLE I. PAYMENT SERVICE PROVIDERS COMPARISION

\begin{tabular}{|c|c|c|c|c|c|c|c|c|c|}
\hline $\begin{array}{l}\text { Payment } \\
\text { service } \\
\text { provider }\end{array}$ & $\begin{array}{l}\text { Setup } \\
\text { Fee }\end{array}$ & $\begin{array}{c}\text { Transaction } \\
\text { Fee }\end{array}$ & $\begin{array}{l}\text { Monthly } \\
\text { Fee }\end{array}$ & Chargeback & $\begin{array}{l}\text { Curren } \\
\text { cies }\end{array}$ & $\begin{array}{c}\text { Target } \\
\text { audience }\end{array}$ & $\begin{array}{c}\text { Fraud } \\
\text { protection }\end{array}$ & $\begin{array}{l}\text { Dispute } \\
\text { handling }\end{array}$ & $\begin{array}{l}\text { Recurring } \\
\text { payments }\end{array}$ \\
\hline \multicolumn{10}{|c|}{ International payment service providers } \\
\hline $\begin{array}{l}\text { Amazon } \\
\text { Payments [5] }\end{array}$ & $\$ 0$ & $3.9 \%+\$ 0.30$ & $\$ 0$ & $\$ 20$ & 12 & All & Yes & Yes & Yes \\
\hline WePay [6] & $\$ 0$ & $2.9 \%+\$ 0.30$ & $\$ 0$ & $\$ 15$ & 2 & $\begin{array}{l}\text { Small } \\
\text { Bussines }\end{array}$ & Yes & No & Discontinued \\
\hline $\begin{array}{l}\text { PayPal } \\
\text { Payments } \\
\text { Standard [7] }\end{array}$ & $\$ 0$ & $4.4 \%+\$ 0.30$ & $\$ 0$ & $\$ 20$ & 24 & All & Yes & Yes & Yes \\
\hline $\begin{array}{l}\text { Authorize.NET } \\
{[8]}\end{array}$ & $\$ 0$ & $2.9 \%+\$ 0.30$ & $\$ 25$ & N/A & 11 & All & Yes & No & Yes \\
\hline Stripe [9] & $\$ 0$ & $3.9 \%+\$ 0.30$ & $\$ 0$ & $\$ 15$ & 135 & All & Yes & Yes & Yes \\
\hline Worldpay [10] & $\$ 0$ & $2.75 \%+\$ 0.26$ & $\$ 0$ & $\$ 15.50$ & 32 & All & Yes & Yes & Yes \\
\hline $\begin{array}{l}\text { Simplify } \\
\text { Commerce [11] }\end{array}$ & $\$ 0$ & $2.45 \%+\$ 0.28$ & $\$ 0$ & N/A & N/A & $\begin{array}{l}\text { Small } \\
\text { Bussines }\end{array}$ & Yes & No & Yes \\
\hline Braintree [12] & $\$ 0$ & $2.9 \%+\$ 0.34$ & $\$ 0$ & $\$ 15$ & 130 & All & Yes & Yes & Yes \\
\hline \multicolumn{10}{|c|}{ Ukrainian payment service providers } \\
\hline LiqPay [13] & $\$ 0$ & $2.75 \%$ & $\$ 0$ & N/A & 1 & $\begin{array}{l}\text { Small } \\
\text { Bussines }\end{array}$ & Yes & No & Yes \\
\hline Interkassa [14] & $\$ 0$ & $3 \%$ & $\$ 0$ & N/A & 1 & $\begin{array}{l}\text { Small } \\
\text { Bussines }\end{array}$ & Yes & No & No \\
\hline EasyPay [15] & $\$ 0$ & $2.7 \%$ & $\$ 0$ & N/A & 1 & $\begin{array}{l}\text { Small } \\
\text { Bussines } \\
\end{array}$ & Yes & No & Yes \\
\hline
\end{tabular}

Despite having the largest transaction fees (Table I.), PayPal is the most popular payment service provider in the world (Fig. 1). This is the result of good marketing, low fees for the transactions inside US and friendly customer services.
In Ukraine there are few large internet payment service providers, some are products of the large Ukrainian banks, like LiqPay, which is developed and supported by Privat bank, others are the branches of popular Russian payment providers. 
Despite having many Ukrainian internet payment service providers, with a reasonable transaction fees, smooth payment process and easy integration into popular ecommerce software, $13 \%$ of Ukrainian buyers use direct card to card payments, $78 \%$ prefer cash on delivery and only $18 \%$ of internet buyers in Ukraine prefer to pay for their orders using payment cards online [16].

Since only a small amount of buyers prefer credit card payments, many store owners implement manual payment processing in their order processing flow, which has lower fees but reasonable only up to certain monthly sales amount, which depends on the number of orders and average order value.

Monthly sales threshold, when manual payment processing is no longer reasonable, was calculated. For this calculations payment processor with a lowest transaction fee for Ukraine $(\mathrm{T}=0.027)$ was used. To compare online and offline payment processing expenses we express transaction processing fees in both cases as a function of the store monthly sales amount, average order value and other variables and constants.

Monthly cost of the transaction processing using payment processor is a linear function of the monthly sales amount:

$$
S_{\text {tp online }}=S \times T
$$

where

$$
\begin{array}{ll}
S_{t p \text { online }} & \text { is the transactions processing price } \\
S & \text { is the monthly store sales amount } \\
T & \text { is the single transaction processing fee }
\end{array}
$$

Monthly cost of the manual transaction processing depends on a few additional variables:

$$
S_{\text {tp offline }}=S A \times\left\lceil\frac{S / A * t_{p}}{t_{w}}\right\rceil
$$

where

$\begin{array}{ll}S_{t p ~ o f f l i n e} & \text { is the transaction processing price } \\ S A & \text { is the salary amount of the worker } \\ S & \text { is the monthly store sales amount } \\ \text { A } & \text { is the store average order value } \\ t_{p} & \text { is the transaction processing time } \\ t_{w} & \text { is the monthly working time }\end{array}$

Based on Equation (1) and Equation (2) and some assumptions about average order value (AOV), worker salary amount and transaction processing time, transaction processing using online payment processor and manual payment processing can be compared numerically.

Reference [17] states that average salary of the employee of the internet store in Ukraine in 2019 is 7000 UAH. Average order value in the small internet store can be as low as $100 \mathrm{UAH}$. Transaction processing time - is the time in minutes required to process one transaction manually. That includes receiving successful payment confirmation from the customer, finding payment in the bank statement and updating order status using the e-store software. It can be as low as 5 minutes, but in certain cases it can be much higher.

Fig. 2 compares transaction processing costs for small internet store with an average order value of $100 \mathrm{UAH}$ in Ukraine for both online and manual payment processing methods.

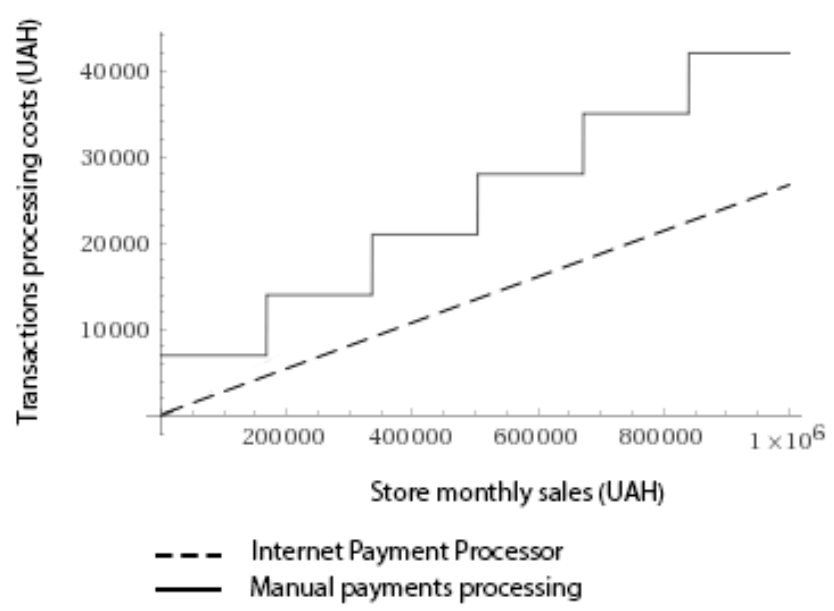

Fig. 2. Comparision of the transaction processing costs for store with AOV of $100 \mathrm{UAH}$

But for stores with a higher average order value situation is totally different. With increase of sales amount, total internet payment processor transaction fees are increasing linearly, but manual payment processing cost stays at the same amount (see Fig. 3). For such cases manual payment processing is much cheaper.

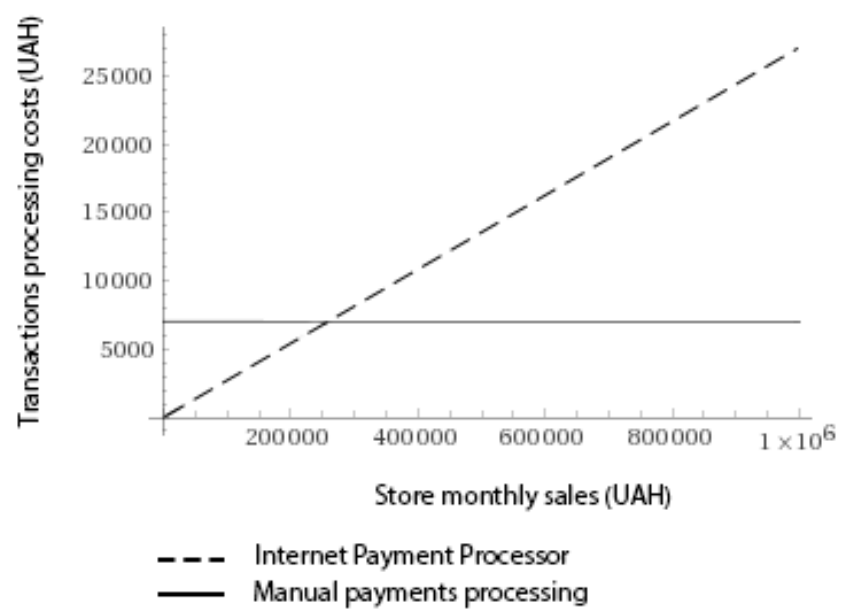

Fig. 3. Comparision of the transaction processing costs for store with AOV of $1000 \mathrm{UAH}$

\section{RESULTS}

As a result of this work, popular international and Ukrainian internet payment service providers were compared by their fees and functionality. Models for estimation of the transaction processing expenses for online and offline payment processing were created.

Online transaction processing model is based on the monthly store sales amount and payment service provider fee only, while manual transaction processing model is more complex and based on the monthly store sales amount, 
average order value, single transaction processing time, worker monthly salary, and monthly working hours. Internet store owners can use those models to determine threshold for switching from offline payment processing to the online payment processing using payment service provider, based on the characteristics of their business.

All internet payment service providers, compared in Table I. do not require any setup fee and monthly payments (except Authorize.NET). The most expensive payment service provider is PayPal Payments Standard $(4.4 \%$ transaction fee), the cheapest - Simplify Commerce $(2.45 \%$ transaction fee). Amazon Payments, PayPal Payments Standard, Authorize.NET, Strip, Worldpay, Braintree are universal payment service providers, supporting all business scales, from the small store to the biggest e-commerce corporations. Strip and Braintree are providers supporting longest list of the world currencies - 135 and 130 respectively. Widely used currencies (US dollars, euro, and British pounds) are supported by PayPal, Authorize.NET and Worldpay.

Ukrainian payment service providers are supporting only one currency - Ukrainian hryvnia. All listed internet payment service providers have fraud protection features. Amazon Payments, PayPal Payments Standard, Stripe, Worldpay, and Braintree have customer dispute handling services that help to build trust between customers and sellers. All payment service providers except WePay and Interkassa support recurring payments.

Fig. 2 shows that manual transaction processing costs more, than online processing for stores with relatively small average order value. Manual processing may be used for such stores with a monthly sales up to $150000 \mathrm{UAH}$, when single person (usually it is a store owner himself) is able to process all payments. If store monthly sales exceed that amount - it is better to invest into integration with internet payment processor.

\section{CONCLUSIONS}

Ukrainian internet payment processors are more affordable and cheap, comparing to the international, but they lack many different features - fraud protection, dispute handling and recurring payments processing.

PayPal is one of the popular international payment processors, which is slightly more expensive than his competitors, but has the best customer protection in the industry.

But all listed international internet payment processors can not be used to accept payments in Ukraine due to the legal issues, and that case makes serving international customers by Ukrainian sellers a highly complicated task.
Most Ukrainian small internet store owners use manual payment processing, which is reasonable only up to certain monthly sales amount, which depends on the number of orders and average order value. For a store with small average order value it is reasonable to process payments manually only up to monthly sales of $150000 \mathrm{UAH}$, when a single person is able to process all payments. In the stores with a larger average order value it may be reasonable to process manually even with a bigger amounts of monthly sales, but manual work can be prone to errors. And error in such a delicate task can lead to the loss of income or trust with the customers.

\section{REFERENCES}

[1] S.V. Zasanska, "Analysis of Electronic Payment Systems in the Financial Market", Scientific Notes of the National University of Ostroh Academy, no. 1, pp. 337-339, 2012.

[2] N.P. Yurchuk, "Features of Payment Environment in the ECommerce System in Ukraine", Economics. finances. management: current issues of science and practice, no. 6, pp.157-170, 2017.

[3] Y.V. Mashyk, "E-Commerce - Internet Payment Systems". Scientific Bulletin of NLTU of Ukraine, no. 21.8, p. 344-348, 2011.

[4] How to Choose a Payment Gateway for Your Online Store [Online]. Available: https://whidegroup.com/blog/how-to-choose-a-paymentgateway-for-your-online-store. Accessed on July 13, 2019.

[5] Amazon [Online]. Available: https://www.amazon.com. Accessed July 13, 2019.

[6] WePay [Online]. Available: https://go.wepay.com. Accessed July 13, 2019.

[7] PayPal [Online]. Available: https://www.paypal.com/ua/home. Accessed on July 13, 2019.

[8] Authorize.net [Online]. Available: https://www.authorize.net. Accessed on July 13, 2019.

[9] Stripe [Online]. Available: https://stripe.com. Accessed on July 13, 2019.

[10] Worldpay [Online]. Available: https://www.worldpay.com. Accessed on July 13, 2019.

[11] Simplify Commerce [Online]. Available: https://www.simplify.com/commerce. Accessed on July 13, 2019.

[12] Braintree [Online]. Available: https://www.braintreepayments.com. Accessed on July 13, 2019.

[13] LiqPay [Online]. Available: https://www.liqpay.ua/ru. Accessed on July $13,2019$.

[14] Interkassa [Online]. Available: https://www.interkassa.com. Accessed on July 13, 2019.

[15] EasyPay [Online]. Available: https://acquiring.easypay.ua. Accessed on July 13, 2019.

[16] V.A. Pavlova, "On the Problems of Development of Online Commerce in Ukraine”, Nobel Economic Bulletin, no. 1, pp. 349-354, 2014.

[17] Overview of statistics on the salary of the employees in online stores in Ukraine [Online]. Available: https://ua.trud.com/salary/2/83912.html. Accessed on July 13, 2019. 